\title{
Effect of red mold rice supplements on serum and meat cholesterol levels of broilers chicken
}

Received: 21 August 2005 / Revised: 10 October 2005 / Accepted: 17 October 2005 / Published online: 17 November 2005

(C) Springer-Verlag 2005

\begin{abstract}
Monacolin $\mathrm{K}$ is a secondary metabolite produced by Monascus species. It was found that it is able to decrease cholesterol levels. In this study, red mold rice (RMR) was added to the diet of Arbor Acres broiler chickens, and the cholesterol level in meat, as well as the concentration of triglyceride, the high-density lipoprotein cholesterol (HDL-C), and the low-density lipoprotein cholesterol (LDL-C) in the serum were evaluated. Fourweek-old broilers are studied and divided into four groups in that each group contains 15 subjects. A 3-week experimental feeding trial was conducted in which three groups of broilers were fed 2.0, 5.0, and $8.0 \%$ of RMR (RMR groups) within their diet, respectively, and the result was compared to the control group. The results indicated that for each RMR group, the cholesterol content was significantly lower than that of the control group; in addition, their meat products contain higher level of unsaturated fatty acids. Triglyceride and cholesterol concentration in serum was also found to be considerably lower in RMR groups when compared to control group. Finally, in RMR groups, HDL-C/LDL-C and HDL-C/ cholesterol ratios were all higher than those of the control
\end{abstract}

\footnotetext{
J.-J. Wang $(\bowtie) \cdot$ M.-J. Shieh

Department of Biotechnology, Tajen University,

20 Weishin Road, Yanpu Shiang,

Ping Tung 907, Taiwan, Republic of China

e-mail: citrinin.tw@yahoo.com.tw

Tel.: +886-8-7624002

Fax: $+886-7-7436458$

T.-M. Pan

Institute of Microbiology and Biochemistry,

National Taiwan University,

Taipei, Taiwan, Republic of China

C.-C. Hsu

Graduate Institute of Pharmaceutical Technology,

Tajen University,

Ping Yung, Taiwan, Republic of China
}

group. In short, the results demonstrated that the cholesterol levels could be lowered by adding RMR to the diet of chickens.

\section{Introduction}

The diet nowadays usually contains excessive levels of cholesterol and fatty acids, which leads to cardiovascular diseases. The relationship between cholesterol and atherosclerosis has long been a concern. Furthermore, plasma total cholesterol and low-density lipoprotein cholesterol (LDL-C) are closely related to atherosclerosis, and excessive concentration of these two substances may lead to coronary artery disease or death (Pekkanen et al. 1992). Therefore, lowering the level of cholesterol in one's diet has become an important concern for senior citizens and patients with cardiovascular diseases.

Chicken is one of the main meat products consumed by humans. It is low in cholesterol and fat and thus is considered to be healthier than other meat products, especially the red meat of mammalian origin. Chicken meat cholesterol content can be altered by varying the composition of diet, age, and gender. Copper, in general, can serve as the growth promoter in poultry and can affect the metabolism of the fatty acid and cholesterol in broiler (Skrivan et al. 2000). Oats are also utilized as the additive in the diet of chickens to enhance the stability of lipids inside chicken meat and reduced the chance for oxidation of cholesterol (Lopez-Bote et al. 1998). Ponte et al. (2004) have demonstrated that alfalfa, an additive that is widely used in animal diet, is an abundant source of protein and contains lower energy capacity. Furthermore, a dehydrated alfalfa meal, high in fiber and saponins content, can enhance the taste of the meal and reduce cholesterol contents within chicken meat. Lastly, other substances such as omega-3 fatty acids (Ayerza et al. 2002), garlic (Konjufca et al. 1997), and $\alpha$-tocopheryl acetate (Ashgar et al. 1989) were added to the diet to improve fatty acid composition as well as cholesterol contents in the meat products. 
The oxidative status of meat can be assessed on the basis of lipid hydroperoxide value and malondialdehyde (MDA) value. Grau et al. (2001) suggested that the addition of linseed, sunflower, and oxidized sunflower oils could increase meat susceptibility to oxidation. In addition, the results of earlier studies have indicated that some dietary antioxidants may be absorbed and thus may prevent lipid deterioration in meats to limited extent (Bartov and Bornstein 1997).

Red mold rice (RMR) has been used in food and folk medicine for thousands of years in Asian nations. The traditional method in making RMR was to ferment the Monascus spp. naturally on a bed of cooked, nonglutinous whole rice kernels. Monacolin K is a secondary metabolite of Monascus species. Endo (1979) discovered a more active methylated form of compactin known as monacolin $\mathrm{K}$ in broths of Monascus ruber. Monacolin K inhibits the activity of 3-hydroxy-3-methylglutaryl coenzyme A (HM G-CoA) reductase in cholesterol biosynthesis, namely, the conversion of HMG-CoA to mevalonate, catalyzed by HMG-CoA reductase (Tobert et al. 1982). Since RMR possesses the properties for lowering cholesterol level and blood pressure, it has been developed into functional health food for human dietary supplement (Manzoni et al. 1999). In addition, previous research has verified that by feeding egg-laying hens RMR, egg cholesterol concentration can be lowered (Wang and Pan 2003).

The objective of this study is to investigate the effect of RMR supplementation with varying concentration on meat quality (cholesterol, fatty acids, and MDA), serum cholesterol, triglyceride high-density lipoprotein cholesterol (HDL-C), and LDL-C in Arbor Acres broiler chickens. To our knowledge, the effects of RMR on meat cholesterol have yet to be investigated in previous studies.

\section{Materials and methods}

Microorganism and seed cultures

The screening for RMR production was performed in our laboratory using the species Monascus purpureus NTU 803. The cultures were maintained on slanted potato dextrose agar (PDA) at $10^{\circ} \mathrm{C}$ and transferred monthly. Seed cultures were prepared by transferring a loopful of spore from the PDA agar slanted into a 500-ml Hinton flask containing $100 \mathrm{ml}$ basal medium (100 g dextrose, $10 \mathrm{~g}$ peptone, $2 \mathrm{~g} \mathrm{KNO}_{3}, 2 \mathrm{~g} \mathrm{NH}_{4} \mathrm{H}_{2} \mathrm{PO}_{4}, 0.5 \mathrm{~g} \mathrm{MgSO}_{4} \cdot 7 \mathrm{H}_{2} \mathrm{O}$, $0.1 \mathrm{~g} \mathrm{CaCl}_{2}$ dissolved in $1,000 \mathrm{ml}$ distilled water, $\mathrm{pH} 6.0$ ). The cultures were incubated at $30^{\circ} \mathrm{C}$ for $48 \mathrm{~h}$ at $110 \mathrm{rpm}$. After that, $5 \%$ seed culture suspension was transferred for solid state fermentation (Wang and Pan 2003).

\section{Solid state fermentation and RMR preparation}

The RMR preparation method was proposed in our previous studies (Wang and Pan 2003). Long-grain rice was purchased from local supermarket and was used as the substrate for RMR production under solid state cultivation. Five hundred grams of long-grain rice (Ipomoea batatas) was soaked in distilled water at room temperature for $8 \mathrm{~h}$, then excess water was removed with a sieve. The soaked rice was autoclaved for $20 \mathrm{~min}$ at $121^{\circ} \mathrm{C}$ in a "koji-dish" (the koji-dish is made of wood with dimensions of $30 \times$ $20 \times 5 \mathrm{~cm}$ ). After being cooled, the substrate was inoculated with a $5 \%(\mathrm{v} / \mathrm{w})$ spore suspension of $M$. purpureus NTU803, and the inoculated substrate was cultivated at $30^{\circ} \mathrm{C}$ for 10 days. The dried rice was then mechanically crushed into powder, and the resulting product was called RMR and was used as a supplement to the basal diet.

\section{Experimental design}

In this study, RMR with monacolin $\mathrm{K}$ was used as the additive in the feed diet to lower cholesterol. A feeding trial was conducted in broilers from 28 to 42 days of age. Sixty Arbor Acres broiler chickens were evenly divided at random into four treatment groups and was placed on one of the following four dietary treatments: basal diet (control group) or basal diet supplemented with 2.0, 5.0, and 8.0\% RMR (RMR groups); monacolin K concentrations in the feed diet of the RMR groups are equivalent to $0.014,0.035$, and $0.056 \%$, respectively. The composition of the basal diet is shown in Table 1. The broilers were housed at random in cages with three birds per cage. Ad libitum food and water were provided throughout the experimental

Table 1 Composition and calculated analysis of basal diets

\begin{tabular}{|c|c|}
\hline Ingredient & Percent \\
\hline Corn & 58.0 \\
\hline Soybean meal & 30.0 \\
\hline Soybean oil & 3.3 \\
\hline Fish meal & 2.0 \\
\hline Corn gluten meal & 3.0 \\
\hline Limestone & 1.0 \\
\hline DL-Methionine & 0.2 \\
\hline Dicalcium phosphate & 1.3 \\
\hline Sodium chloride & 0.2 \\
\hline Vitamin $^{\mathrm{a}}$ and mineral premix ${ }^{\mathrm{b}}$ & 1.0 \\
\hline Total & 100.0 \\
\hline \multicolumn{2}{|l|}{ Calculated and determined analysis } \\
\hline Crude protein & 15.50 \\
\hline Fat & 6.50 \\
\hline Total phosphate & 0.56 \\
\hline Calcium & 0.80 \\
\hline Lysine & 0.90 \\
\hline Methionine & 0.55 \\
\hline Metabolizable energy (kcal/kg) & $3,100.00$ \\
\hline \multicolumn{2}{|c|}{$\begin{array}{l}\text { a'Vitamin premix supplied the following (per kilogram of basal } \\
\text { diet): vitamin A, } 12,600 \mathrm{IU} \text {; vitamin } \mathrm{D}_{3}, 2,200 \mathrm{ICU} \text {; vitamin } \mathrm{E} \text {, } \\
10 \mathrm{IU} \text {; vitamin } \mathrm{K}, 3.5 \mathrm{mg} \text {; riboflavin } 6.6 \mathrm{mg} \text {; niacin, } 40.0 \mathrm{mg} \text {; } \\
\text { pantothenic acid, } 14.4 \mathrm{mg} \text {; vitamin } \mathrm{B}_{12}, 0.012 \mathrm{mg} \text {; folic acid, } \\
1.0 \mathrm{mg} \text {; pyridoxine, } 1.2 \mathrm{mg} \\
\text { b } \mathrm{Mineral} \mathrm{premix} \mathrm{supplied} \mathrm{the} \mathrm{following} \mathrm{(per} \mathrm{kilogram} \mathrm{of} \mathrm{basal} \mathrm{diet)} \\
\mathrm{Mn}, 55 \mathrm{mg} \text {; } \mathrm{Cu}, 10 \mathrm{mg} \text {; } \mathrm{Zn}, 50 \mathrm{mg} ; \mathrm{Fe}, 30 \mathrm{mg}\end{array}$} \\
\hline
\end{tabular}


period. Feed consumption and conversion were calculated from body and feed weights taken at the end of the test.

\section{Sample preparation}

At the end of the 21-day experimental period, broilers were fasted overnight, and the blood samples were collected from the vein on the brachial wing of each bird. Cholesterol, triglyceride, and LDL-C and HDL-C concentrations were determined using a commercial diagnostic kits provided by Cobas Mira (Roche Diagnostic Systems Inc., Montclair, NJ, USA). The broilers were killed by conventional methods. Thigh muscles, breast muscles, and liver tissues were separated from broilers, and skin and visible fat were removed.

\section{Cholesterol measurement}

One gram of muscle sample was homogenized using Polytron PT 2000 for $30 \mathrm{~s}$ at $19,800 \mathrm{rpm}$ with $5 \mathrm{ml}$ of absolute ethanol. Ten millimeters of $1.6 \mathrm{~N}$ methanolic $\mathrm{KOH}$ was then added, and saponification was carried out at $70^{\circ} \mathrm{C}$ for $30 \mathrm{~min}$. $5 \alpha$-Cholesterol was used as internal standard for cholesterol assay. Nonsaponifiable materials were then extracted with $n$-hexane, transferred to vials, and sealed for cholesterol analysis by Hewlett-Packard gas chromatograph (model 5890; Hewlett-Packard Co., Wilmington, DE, USA) equipped with flame ionization detector. GC conditions were as follows. DB-1 fused silica capillary column $(30 \mathrm{~m} \times 0.25 \mathrm{~mm}, 0.25-\mu \mathrm{m}$ film thickness): the initial temperature was held at $70^{\circ} \mathrm{C}$ for $2 \mathrm{~min}$, then increased at $10^{\circ} \mathrm{C} \min ^{-1}$ to $100^{\circ} \mathrm{C}$ and, finally, increased at $20^{\circ} \mathrm{C} \mathrm{min}{ }^{-1}$ to $285^{\circ} \mathrm{C}$. Injector temperature was set at $300^{\circ} \mathrm{C}$, and the detector temperature was maintained at $315^{\circ} \mathrm{C}$. Nitrogen was used as the carrier gas at a flow rate

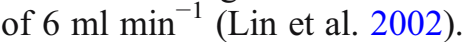

\section{Determination of fatty acid composition}

The method for determining fatty acids was proposed by Rule (1997). Methyl esters of fatty acids from the extracted lipid were prepared using $2 \mathrm{ml}$ of $14 \% \mathrm{BF}_{3}$-methanol solution trans-esterification procedure. Methyl $n$-pentadecaoate was used as fatty acid internal standard. The fatty acid methyl esters were separated by Hewlett-Packard gas chromatograph (GC) equipped with a flame ionization detector. GC conditions were as follows. CP-Wax $(0.53 \mathrm{~mm} \times$ $30 \mathrm{~m}$ ) capillary column: the temperature was programmed from $170^{\circ} \mathrm{C}$ (maintained for $2 \mathrm{~min}$ ) to $240^{\circ} \mathrm{C}$ (maintained for $5 \mathrm{~min}$ ) at a rising rate of $4^{\circ} \mathrm{C} \mathrm{min}^{-1}$. Injector temperature was set at $260^{\circ} \mathrm{C}$, and the detector temperature was maintained at $280^{\circ} \mathrm{C}$. Nitrogen was used as carrier gas at a flow rate of $20 \mathrm{ml} \mathrm{min}^{-1}$.
Determination of liver tissue cholesterol and triglyceride

Liver samples were homogenized with $0.25 \mathrm{M}$ saccharose and $0.1 \mathrm{M}$ phosphate buffer ( $\mathrm{pH}$ 7.4). Homogenates obtained were then centrifugated, and supernatants were separated. Total cholesterol and triglyceride levels were measured spectrophotometrically (Aletor et al. 2003).

\section{Measurement of lipid oxidation}

Lipid oxidation was measured using the 2-thiobarbituric acid (TBA) method proposed by Salih et al. (1987). The 2thiobarbutric acid reactive substance (TBARS) was expressed in milligram MDA per kilogram of meat.

\section{Determination of the monacolin $\mathrm{K}$ concentration}

One gram of RMR was extracted with $5 \mathrm{ml}$ of ethyl acetate at $70^{\circ} \mathrm{C}$ for $1.5 \mathrm{~h}$. The suspension was then filtered through filter paper. The filtrate was dried under vacuum. After lactonization, $1 \mathrm{ml}$ of acetonitrile was added to the resulting mixture, followed by filtration with a $0.45-\mu \mathrm{m}$ pore size filter and analyzed by high-performance liquid chromatography (HPLC; model L-6200, Hitachi Co., Japan) (Wang et al. 1998). Chromatographic separation was conducted on a Beckman Ultrasphere ODS column $(150 \mathrm{~mm} \times$ $4.6 \mathrm{~mm}$ i.d.). Acetonitrile-phosphoric acid (0.5\%, 65:35, $\mathrm{v} / \mathrm{v}$ ) was used as the mobile phase. The eluent was pumped at a flow rate of $0.7 \mathrm{ml} \mathrm{min}^{-1}$. Ultraviolet (UV) was set at $238 \mathrm{~nm}$.

\section{Statistical analyses}

All data obtained in the experiment were subjected to the analysis of variance (ANOVA). Means were separated using Duncan's test for multiple comparisons. Statistical significance was then determined based on $p<0.05$. These analyses were conducted by using statistical analysis software SPSS, release 9.0 (SPSS, Inc.).

\section{Results}

Effect of RMR on the body weight, feed intake, and conversion

Effect of RMR content in feed diet on body weight gain, feed consumption, and feed conversion is shown in Table 2. Even though the weight of RMR groups was found to be lower than that of the control group, after 21 days of feeding, the results showed that RMR had no significant effect on body weight change $(p<0.05)$. In addition, the feed consumption and feed conversion were 
Table 2 Effect of red mold rice on broiler performance: body gain, feed intake, and feed conversion

\begin{tabular}{llll}
\hline $\begin{array}{l}\text { Red mold } \\
\text { rice }(\%)\end{array}$ & $\begin{array}{l}\text { Weight } \\
\text { gain }(\mathrm{g})\end{array}$ & $\begin{array}{l}\text { Feed Intake } \\
\left(\mathrm{g} \mathrm{bird}^{-1} \text { day }^{-1}\right)\end{array}$ & $\begin{array}{l}\text { Feed conversion } \\
{[\mathrm{kg} \text { feed }} \\
\left.\left(\mathrm{kg} \mathrm{meat}^{-1}\right)\right]\end{array}$ \\
\hline 0 & $1439.17 \pm 83.81^{\mathrm{a}}$ & $119.83 \pm 7.79^{\mathrm{a}}$ & $1.75 \pm 0.08^{\mathrm{a}}$ \\
2.0 & $1422.17 \pm 100.77^{\mathrm{a}}$ & $128.83 \pm 5.85^{\mathrm{ab}}$ & $1.91 \pm 0.21^{\mathrm{ab}}$ \\
5.0 & $1407.67 \pm 52.36^{\mathrm{a}}$ & $135.51 \pm 7.79^{\mathrm{b}}$ & $2.02 \pm 0.15^{\mathrm{b}}$ \\
8.0 & $1393.50 \pm 65.89^{\mathrm{a}}$ & $130.16 \pm 8.25^{\mathrm{b}}$ & $1.96 \pm 0.13^{\mathrm{b}}$ \\
\hline
\end{tabular}

The duration of the experiment was 21 days. Data are presented as means \pm SD. Mean values within each column with different superscripts are significantly different $(p \leq 0.05)$

higher in the RMR groups when compared to the control group, and the results indicated that RMR had significant effect on feed consumption and feed conversion.

\section{Meat and liver lipid concentration}

Table 3 showed the effect of dietary treatment on the concentrations of triglycerides and cholesterol in liver. The triglyceride contents within the liver of broilers of the RMR group were significantly lower than those in the control group. Moreover, the lowering ratio, according to its additive concentration, has reached to $52.12,49.94$, and $38.97 \%$, respectively. In addition, the cholesterol content in the liver of broilers of RMR group demonstrated significant difference from that of the control group; its lowering ratio, according to the additive concentration, has reached to $7.73,15.60$, and $29.75 \%$, respectively. Lastly, as illustrated in Table 3, the cholesterol content within the breast and thigh muscle of broiler of RMR group was significantly lower than that of the control group. The lower ratio of breast muscle, according to its additive concentration, has reached to $12.30,31.78,8.65 \%$, respectively. The cholesterol level of the broilers with $5 \%$ RMR additive in the diet has the highest lowering ratio, and the lowering ratio cholesterol in the thigh muscle has reached to $13.43,24.55,8.95 \%$, respectively. Thus, $5 \%$ of the RMR additive in the diet has proven to be the most suitable additive concentration.

Table 3 Effect of red mold rice on broiler performance: liver and muscle triglyceride and cholesterol

\begin{tabular}{|c|c|c|c|c|}
\hline \multirow[t]{2}{*}{$\begin{array}{l}\text { Red mold } \\
\text { rice }(\%)\end{array}$} & \multicolumn{2}{|c|}{ Liver $\left(\mathrm{mg} \mathrm{g}^{-1}\right)$} & \multicolumn{2}{|c|}{$\begin{array}{l}\text { Muscle cholesterol } \\
{\left[\left(\mathrm{mg}\left(100 \mathrm{~g}^{-1}\right)\right]\right.}\end{array}$} \\
\hline & Triglyceride & Cholesterol & Breast & Thigh \\
\hline 0 & $48.22 \pm 4.02^{\mathrm{a}}$ & $7.63 \pm 0.92^{\mathrm{a}}$ & $61.02 \pm 3.83^{\mathrm{a}}$ & $76.74 \pm 5.61^{\mathrm{a}}$ \\
\hline 2.0 & $23.09 \pm 3.74^{\mathrm{b}}$ & $7.04 \pm 0.79^{\mathrm{ab}}$ & $53.51 \pm 4.96^{\mathrm{b}}$ & $66.43 \pm 6.68^{\mathrm{bc}}$ \\
\hline 5.0 & $24.14 \pm 3.93^{b c}$ & $6.44 \pm 0.85^{\mathrm{b}}$ & $41.63 \pm 6.87^{\mathrm{c}}$ & $57.90 \pm 8.08^{\mathrm{b}}$ \\
\hline 8.0 & $29.43 \pm 6.82^{\mathrm{c}}$ & $5.36 \pm 0.87^{\mathrm{c}}$ & $55.74 \pm 5.05^{\mathrm{ab}}$ & $69.87 \pm 7.38^{\mathrm{ac}}$ \\
\hline
\end{tabular}

The duration of the experiment was 21 days. Data are presented as means $\pm \mathrm{SD}(n=15)$. Mean values within each column with different superscripts are significantly different $(p \leq 0.05)$
Table 4 Effect of red mold rice on broiler performance: fatty acid composition of the breast muscle

\begin{tabular}{|c|c|c|c|c|}
\hline \multirow{3}{*}{$\begin{array}{l}\text { Fatty } \\
\text { acid }\end{array}$} & \multicolumn{4}{|c|}{ Red mold rice content } \\
\hline & $0 \%$ & $2.0 \%$ & $5.0 \%$ & $8.0 \%$ \\
\hline & \multicolumn{4}{|c|}{ (\% of total fatty acids) } \\
\hline 16:0 & $26.72 \pm 1.65^{\mathrm{a}}$ & $24.87 \pm 0.89^{\mathrm{a}}$ & $25.42 \pm 0.74^{\mathrm{a}}$ & $25.97 \pm 0.37^{\mathrm{a}}$ \\
\hline 16:1 & $1.48 \pm 0.46^{\mathrm{a}}$ & $1.63 \pm 0.33^{\mathrm{a}}$ & $2.60 \pm 1.10^{\mathrm{b}}$ & $1.64 \pm 0.19^{\mathrm{a}}$ \\
\hline 18:0 & $15.25 \pm 1.07^{\mathrm{a}}$ & $13.07 \pm 0.26^{\mathrm{b}}$ & $11.22 \pm 1.67^{\mathrm{b}}$ & $12.28 \pm 0.16^{\mathrm{b}}$ \\
\hline 18:1 & $28.22 \pm 1.23^{\mathrm{a}}$ & $31.20 \pm 0.99^{\mathrm{b}}$ & $30.98 \pm 2.29^{b}$ & $31.02 \pm 0.26^{\mathrm{b}}$ \\
\hline $18: 2$ & $22.91 \pm 1.79^{\mathrm{a}}$ & $25.25 \pm 0.66^{\mathrm{b}}$ & $24.01 \pm 0.80^{\mathrm{ab}}$ & $25.07 \pm 0.39^{\mathrm{b}}$ \\
\hline $18: 3$ & $1.42 \pm 0.31^{\mathrm{a}}$ & $1.59 \pm 0.25^{\mathrm{a}}$ & $1.83 \pm 0.13^{\mathrm{a}}$ & $1.53 \pm 0.32^{\mathrm{a}}$ \\
\hline $20: 0$ & $0.48 \pm 0.06^{\mathrm{a}}$ & $0.39 \pm 0.01^{\mathrm{a}}$ & $1.30 \pm 0.22^{\mathrm{b}}$ & $0.44 \pm 0.08^{\mathrm{a}}$ \\
\hline 20:5 & $0.84 \pm 0.11^{\mathrm{a}}$ & $0.82 \pm 0.09^{\mathrm{a}}$ & $0.25 \pm 0.06^{\mathrm{b}}$ & $0.83 \pm 0.03^{\mathrm{a}}$ \\
\hline MUFA & $29.71 \pm 1.16^{\mathrm{a}}$ & $32.83 \pm 0.79^{\mathrm{ab}}$ & $33.59 \pm 3.12^{\mathrm{b}}$ & $32.66 \pm 0.35^{\mathrm{ab}}$ \\
\hline PUFA & $25.15 \pm 2.03^{\mathrm{a}}$ & $27.67 \pm 0.50^{\mathrm{b}}$ & $26.09 \pm 0.77^{\mathrm{ab}}$ & $27.43 \pm 0.33^{b}$ \\
\hline Saturated & $42.46 \pm 3.83^{\mathrm{a}}$ & $38.33 \pm 1.09^{\mathrm{ab}}$ & $37.95 \pm 2.45^{\mathrm{a}}$ & $38.69 \pm 0.27^{\mathrm{a}}$ \\
\hline $\mathrm{P} / \mathrm{S}$ & $0.59 \pm 0.06^{\mathrm{a}}$ & $0.72 \pm 0.02^{\mathrm{b}}$ & $0.69 \pm 0.03^{b}$ & $0.71 \pm 0.01^{\mathrm{b}}$ \\
\hline $\mathrm{P}+\mathrm{M} / \mathrm{S}$ & $1.30 \pm 0.14^{\mathrm{a}}$ & $1.58 \pm 0.05^{\mathrm{b}}$ & $1.58 \pm 0.15^{\mathrm{b}}$ & $1.55 \pm 0.02^{\mathrm{b}}$ \\
\hline
\end{tabular}

Values are mean \pm SE of 15 broilers. Mean values within each column with different superscripts are significantly different $(p \leq 0.05)$

Fatty acid profile in the breast and thigh muscles

The influence of the dietary treatments on the concentration of individual fatty acids is shown in Tables 4 and 5. As for the fatty acid contents within the meat muscle, C16:0, C18:1, and C18:2 have the highest contents. Within the fatty acids of breast and thigh muscles, RMR can actually affect the composition of the saturated and unsaturated fatty acids. It seems that by adding RMR into the diet of broilers, more unsaturated fatty acid could be obtained [mono (M)- and polyunsaturated fatty acid (P)]. Moreover, the ratio between unsaturated fatty acids and saturated fatty

Table 5 Effect of red mold rice on broiler performance: fatty acid composition of the thigh muscle

\begin{tabular}{lrrrr}
\hline Fatty & \multicolumn{4}{l}{ Red mold rice content } \\
\cline { 2 - 5 } acid & $\begin{array}{l}\text { 0\% } \\
\text { (\% of total fatty acids })\end{array}$ & & \multicolumn{1}{l}{$5.0 \%$} \\
& (r.0\% & \\
\hline $16: 0$ & $25.42 \pm 0.84^{\mathrm{a}}$ & $24.58 \pm 1.65^{\mathrm{a}}$ & $22.40 \pm 0.77^{\mathrm{b}}$ & $22.22 \pm 1.09^{\mathrm{b}}$ \\
$16: 1$ & $3.56 \pm 0.34^{\mathrm{a}}$ & $4.13 \pm 0.46^{\mathrm{a}}$ & $3.43 \pm 0.86^{\mathrm{a}}$ & $3.33 \pm 0.06^{\mathrm{a}}$ \\
$18: 0$ & $8.85 \pm 0.39^{\mathrm{a}}$ & $8.91 \pm 0.88^{\mathrm{a}}$ & $7.79 \pm 2.10^{\mathrm{a}}$ & $8.49 \pm 0.72^{\mathrm{a}}$ \\
$18: 1$ & $29.43 \pm 0.93^{\mathrm{a}}$ & $27.17 \pm 0.75^{\mathrm{b}}$ & $31.48 \pm 1.12^{\mathrm{c}}$ & $32.61 \pm 1.14^{\mathrm{c}}$ \\
$18: 2$ & $27.83 \pm 1.14^{\mathrm{a}}$ & $28.49 \pm 2.44^{\mathrm{a}}$ & $27.64 \pm 1.39^{\mathrm{a}}$ & $27.45 \pm 1.89^{\mathrm{a}}$ \\
$18: 3$ & $2.14 \pm 0.19^{\mathrm{a}}$ & $2.85 \pm 0.96^{\mathrm{a}}$ & $1.94 \pm 0.06^{\mathrm{a}}$ & $2.24 \pm 0.18^{\mathrm{a}}$ \\
$20: 0$ & $0.28 \pm 0.02^{\mathrm{a}}$ & $0.32 \pm 0.08^{\mathrm{a}}$ & $0.45 \pm 0.38^{\mathrm{b}}$ & $0.32 \pm 0.04^{\mathrm{a}}$ \\
$20: 5$ & $0.30 \pm 0.04^{\mathrm{a}}$ & $0.54 \pm 0.08^{\mathrm{a}}$ & $1.49 \pm 0.53^{\mathrm{b}}$ & $0.71 \pm 0.12^{\mathrm{a}}$ \\
MUFA & $32.99 \pm 1.12^{\mathrm{a}}$ & $31.31 \pm 0.36^{\mathrm{b}}$ & $34.92 \pm 0.35^{\mathrm{c}}$ & $35.95 \pm 1.12^{\mathrm{c}}$ \\
PUFA & $30.27 \pm 1.19^{\mathrm{a}}$ & $31.88 \pm 1.66^{\mathrm{a}}$ & $31.08 \pm 1.95^{\mathrm{a}}$ & $30.41 \pm 1.57^{\mathrm{a}}$ \\
Saturated & $34.55 \pm 0.50^{\mathrm{a}}$ & $33.82 \pm 1.20^{\mathrm{a}}$ & $30.64 \pm 1.05^{\mathrm{b}}$ & $31.03 \pm 1.13^{\mathrm{b}}$ \\
P/S & $0.87 \pm 0.05^{\mathrm{a}}$ & $0.94 \pm 0.07^{\mathrm{ab}}$ & $1.01 \pm 0.08^{\mathrm{b}}$ & $0.98 \pm 0.02^{\mathrm{ab}}$ \\
P+M/S & $1.83 \pm 0.04^{\mathrm{a}}$ & $1.87 \pm 0.09^{\mathrm{a}}$ & $2.15 \pm 0.10^{\mathrm{b}}$ & $2.13 \pm 0.05^{\mathrm{b}}$ \\
\hline
\end{tabular}

Values are mean \pm SE of 15 broilers. Mean values within each column with different superscripts are significantly different $(p \leq 0.05)$ 
Table 6 Effect of red mold rice on broiler performance: serum LDL, HDL, triglyceride, and cholesterol

\begin{tabular}{llllllll}
\hline Red mold rice (\%) & \multicolumn{2}{l}{ Items $\left(\mathrm{mg} \mathrm{dL}^{-1}\right)$} & & \multicolumn{3}{l}{ Ratios } \\
\cline { 2 - 6 } & LDL-C & HDL-C & Triglyceride & Cholesterol & & HDL-C/cholesterol & HDL/LDL \\
\hline 0 & $55.50 \pm 5.76^{\mathrm{a}}$ & $45.67 \pm 4.10^{\mathrm{a}}$ & $151.37 \pm 8.85^{\mathrm{a}}$ & $136.03 \pm 6.34^{\mathrm{a}}$ & $0.335 \pm 0.022^{\mathrm{a}}$ & $0.825 \pm 0.039^{\mathrm{a}}$ \\
2.0 & $50.16 \pm 4.95^{\mathrm{ab}}$ & $43.33 \pm 3.20^{\mathrm{a}}$ & $128.13 \pm 11.14^{\mathrm{b}}$ & $119.32 \pm 4.84^{\mathrm{b}}$ & $0.364 \pm 0.028^{\mathrm{a}}$ & $0.867 \pm 0.053^{\mathrm{ab}}$ \\
5.0 & $46.16 \pm 6.58^{\mathrm{b}}$ & $40.68 \pm 4.97^{\mathrm{a}}$ & $139.21 \pm 7.49^{\mathrm{c}}$ & $116.33 \pm 6.98^{\mathrm{b}}$ & $0.349 \pm 0.031^{\mathrm{a}}$ & $0.884 \pm 0.030^{\mathrm{b}}$ \\
8.0 & $49.17 \pm 3.18^{\mathrm{ab}}$ & $43.66 \pm 4.40^{\mathrm{a}}$ & $140.20 \pm 7.46^{\mathrm{c}}$ & $120.83 \pm 7.55^{\mathrm{b}}$ & $0.362 \pm 0.035^{\mathrm{a}}$ & $0.887 \pm 0.050^{\mathrm{b}}$ \\
\hline
\end{tabular}

The duration of the experiment was 21 days. Data are presented as means \pm SD $(n=12)$. Mean values within each column with different superscripts are significantly different $(p \leq 0.05)$

$L D L-C$ low-density lipoprotein cholesterol, $H D L-C$ high-density lipoprotein cholesterol

acids (S) has an apparent elevation of $(\mathrm{P}+\mathrm{M} / \mathrm{S})$, but did not have any relationship with regard to its dosage effect. Therefore, adding RMR to the diet can effectively change the composition of the fatty aids within the breast and thigh muscles of broiler chickens.

Concentration of cholesterol, triglyceride, HDL-C, and LDL-C within serum

The effect of adding RMR to the broiler's diet on the cholesterol, triglyceride, HDL-C, and LDL-C concentration in the serum is illustrated in Table 6. The RMR group with 5\% RMR in its diet lowered the LDL-C content to $16.83 \%$. Although adding RMR can lower the HDL-C concentration within the serum of broilers, there was no significant functional difference between the RMR group and the control group statistically. The triglyceride was significantly reduced by $15.35 \%$ when $2 \%$ RMR was incorporated into the broiler's diet. In addition, each of RMR groups showed significant difference on the cholesterol contents in the serum when compared to that of the control group. The most noticeable effectiveness is in 5\% RMR group, as the cholesterol content is only $14.48 \%$ in the serum. In addition, it was found that the HDL-C/ cholesterol and HDL-C/LDL-C ratio could be increased by adding RMR to broiler's diet.

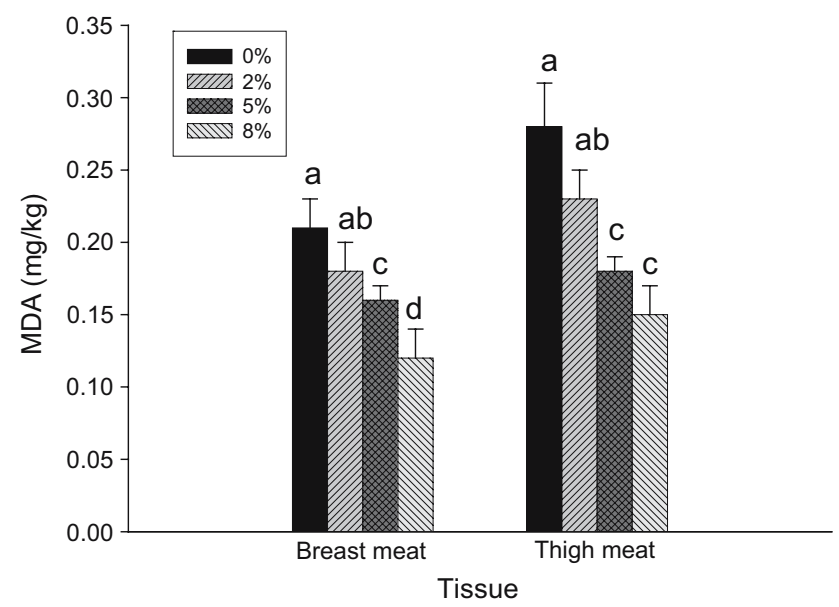

Fig. 1 Effect of red mold rice supplementation on meat tissue MDA levels
MDA concentration in the meat muscle

MDA is one of the by-products of lipid after peroxidation. When reacting with TBA, it will become a red color complex called MDA-TBA. In addition, under 532-nm wavelength, it shows the greatest absorbance and will be directly proportional to MDA concentration. As illustrated in Fig. 1, after a feeding trial of 3 weeks with different concentrations of RMR in broiler diet, a test was done on TBARS concentration to understand the level of reaction by the lipid peroxidation in the broiler meat muscle. The result showed that RMR groups have relatively lower MDA when compared with that of the control group. Also, when comparing within higher dosage groups, significant difference was also found (breast muscle: $0 \%: 0.21 \pm 0.02$, $2 \%$ : $0.18 \pm 0.02,5 \%: 0.16 \pm 0.01,8 \%$ : $0.12 \pm 0.02$; thigh muscle: $0 \%$ : $0.28 \pm 0.03,2 \%: 0.23 \pm 0.02,5 \%: 0.18 \pm 0.01$, $8 \%: 0.15 \pm 0.02 ; p<0.05)$. Therefore, it is obvious that by adding RMR to the broiler's diet, it can lower lipid peroxidation within the broiler meat muscle.

\section{Discussion}

Since RMR possesses the ability to lower cholesterol level and blood pressure, it has been developed into functional health food for human dietary supplement marketed in the United States (Cholestin; Pharmanex, Redwood City, CA). Secondary metabolites produced from filamentous fungus Monascus species include Monascus pigments (red, orange, and yellow pigments; Su and Huang 1976), antibacterial substances (Wong and Koehler 1981), cholesterol synthetic inhibitor-monacolin K (Endo 1979), antihypertensive substances - $\gamma$-aminobutyric acid (GABA) (Kono and Himeno 2000), antioxidant action (Aniya et al. 2000), antitumor promotion action (Yasukawa et al. 1994), and immunosuppressive action (Martinkova et al. 1999). Of all the substances mentioned above, monacolin $\mathrm{K}$ is the most researched substance that will lead to become a cure for hypocholesterolemic disease.

Monacolin $\mathrm{K}$ is able to lower cholesterol content inside the body because it contains HMG-CoA reductase, which is the main enzyme, and can suppress cholesterol synthesis. Studies have shown that lovastatin is capable of suppressing preadipocyte 3T3-L1 from decomposing into adipocyte (Harmon and Harp 2001). RMR extracts can 
significantly decrease glycerol-3-phosphate dehydrogenase activity and lipid accumulation. Moreover, RMR extracts can inhibit peroxisome proliferator-activated receptor $\gamma$ and CCAAT/enhancer-binding protein $\alpha$ gene expression (Jeon et al. 2004). It is probable that weight reduction of broilers is due to the results presented above. Broilers need to maintain energy balance within their body, which resulted in the increase of food intake and therefore resulted in the increase of feed conversion.

Many research reports on nutrition have indicated that one should reduce the ingestion of cholesterol, general fat, and saturated fatty acid to reduce the risk of cardiovascular disease. Therefore, in the recent years, consumers have pay particular attention on cutting down the ingestion of cholesterol and saturated fatty acids and increasing the intake of diversified unsaturated fatty acids to reduce the risk of arteriosclerosis diseases. By adding RMR to broiler's diet, our research found that the cholesterol contents in the broiler meat were reduced, and the ratio between the diversified unsaturated fat and saturated fatty acid was increased. With regard to the cholesterol contents of the broiler meat, in the high dosage group (8\%), there was no apparent relation of dose independent. However, the RMR groups that dealt with RMR still have lower cholesterol when compared to the control group. As we know, cholesterol is an important composition within the cell membrane of animals, and it is also the forerunner that synthesizes hormone and vitamin. The balance of cholesterol within the blood and bodily tissue is an important concept that needs to be addressed. The mechanism of the cholesterol balance is related to inputs (such as composition of diet, liver, and intestine synthesis, to name a few) or outputs (such as the balance of neutral sterol, bile acid) (Naber 1990). In this study, the reduced quantity of cholesterol in the broiler meat does not completely rely on the additive quantity of RMR. Therefore, the existence of hypotheses such as "cholesterol critical level" or "cholesterol balance" can be explained. In addition, regarding the fatty acid contents of broiler meat within breast muscle, C18:1 and C18:2 have increased significantly, yet C18:0 has obviously declined. The RMR groups and the control group have shown significant difference $(p<0.05)$. As for the fatty acids in the thigh muscle, C18:1 of the RMR group has escalated significantly, yet C16:0 has obviously declined, and the difference can be shown statistically. In addition, broiler breast and thigh muscles of RMR group have higher $\mathrm{P} / \mathrm{S}$ or $\mathrm{P}+\mathrm{M} / \mathrm{S}$ ratio than that of the control group. Ayerza et al. (2002) have indicated that by adding substances such as omega-3 fatty acids into broiler's diet, fatty acids composition and cholesterol contents within the meat products can be improved. Lin et al. (2002) have pointed out that fish oil contains diversified unsaturated fatty acid, and if it is utilized as diet additive, it will be able to change the fatty acid composition in the broiler meat. Juzlova et al. (1996) have stated that the metabolic product of the fungus M.purpureus has the ability to produce long chain fatty acids. Among 39 types of fatty acids, there are 22 types of saturated fatty acids, 14 types of monoenoic acids, and 2 types of dienoic and $\alpha$-linolenic acid. In short, the composition of fatty acid in broiler meat can be altered by adding RMR into broiler diet.

The result of this study showed that the cholesterol in the serum can be reduced to $12.28,14.48$, and $11.17 \%$ by adding $2.0,5.0$, and $8.0 \%$ of RMR into chickens' diet, respectively. Triglyceride levels were reduced to 15.35 , 8.03, and 7.38\%, while LDL-C concentrations are reduced to $9.62,16.83$, and $11.41 \%$, respectively. Monacolin K, found in RMR, not only can suppress cholesterol formation with its main enzyme HMG-CoA reductase but can also increase the activity of LDL-C receptor inside the body, increase very low density lipoprotein absorption by the liver, and reduce the conversion of VLDL to LDL-C, which will reduce cholesterol within the body (Pitman et al. 1998). The addition of RMR does not increase HDL-C contents. When compared with HDL-C/LDL-C and HDL-C/ cholesterol ratios, the ratio for the experimental groups is higher than that of the control group. In addition, when compared with the data that were derived from our previous research on egg-laying hens' serum profile, the change in the percentile is slightly different. However, they do exhibit similar results (Wang and Pan 2003). Mori et al. (1999) pointed out that when compared to hypocholesterolemic agents in humans, lovastatin showed similar function in reducing cholesterol, triglyceride, HDL-C, and LDL-C in egg-laying hens. The degree of reduction was correlated to hen's age, lovastatin concentration, and feed time. In addition, it was discovered from Tables 3 and 4 that the change in cholesterol contents of the broiler breast and thigh muscles has a positive correlation with the change in the cholesterol contents in the serum.

The reaction of MDA with TBA is widely used as the means to measure the extent of oxidative deterioration of lipid in the muscle food. MDA is a secondary product of lipid oxidation and prostaglandin biosynthesis with carcinogenic (Boyd and McGuire 1991) and mutagenic effect on bacterial and mammalian cells (Benamira et al. 1995). O'Neill et al. (1999) concluded that tocopherol supplementation was used to prevent the MDA formation and would not affect meat quality. The antioxidant activity of RMR was suggested by Aniya et al. (2000). Aviram et al. (1992) argued that lovastatin had special chemical composition. It was easier to react with metal ions to produce coordination compounds. In other words, lovastatin was an antioxidant and could inhibit lipid peroxidation. They also pointed out that during the oxidation of LDL-C, decreasing the TBARS concentration of lovastatin was related to the duration and dose of lovastatin. Our research team had also proven previously that the addition of RMR to the diet of laying hens can effectively reduce the MDA concentration in the serum (Wang and Pan 2003). This study focuses on the peroxidation condition of lipid in the broiler meat. It has been discovered that the MDA concentration in the experimental group is obviously lower than that of the control group. Therefore, it is obvious that RMR not only can suppress the formation of MDA in serum but also possess the oxidation ability of lipid in broiler meat. This shows that the results in both studies are consistent. 
In view of dietary health, food that contains more unsaturated fatty acid and relatively lower cholesterol contents can help in reducing the occurrence of cardiovascular diseases. By adding RMR to the diet of Arbor Acres broilers, we found that not only the cholesterol, triglyceride, and LDL-C concentration in the serum were reduced, the cholesterol contents in meat muscle were also decreased. Furthermore, unsaturated fatty acid contents were increased. Therefore, the application of RMR as an additive to broiler's diet seems to be feasible and worthwhile.

\section{References}

Aletor VA, Eder K, Becker K, Paulicks BR, Roth FX, Roth-Maier DA (2003) The effect of conjugated linoleic acid or an $\alpha$ glucosidase inhibitor on tissue lipid concentrations and fatty acid composition of broiler chicks fed a low-protein diet. Poult Sci 82:796-804

Aniya Y, Ohtani II, Higa T, Miyagi C, Gibo H, Shimabukuro M, Nakanish H, Taira J (2000) Dimerumic acid as an antioxidant of the mold: Monascus anka. Free Radic Boil Med 28:999-1004

Ashgar A, Lin CF, Gray JI, Buckley DJ, Booren AM, Crackei R, Flegai CJ (1989) Influence of oxidized dietary oil and antioxidant supplementation on membrane bound lipid stability in broiler meat. Br Poult Sci 30:815-823

Aviram M, Dankner G, Cogan U, Hochgraf E, Brook JG (1992) Lovastatin inhibitors low-density lipoprotein oxidation and alters its fluidity and uptake by macrophages: in vitro and in vivo studies. Metabolism 41:229-235

Ayerza R, Coates W, Lauria M (2002) Chia seed (Salvia hispanica L.) as an [omega]-3 fatty acid source for broilers: influence on fatty acid composition, cholesterol and fat content of white and dark meats, growth performance and sensory characteristics. Poult Sci 81:826-837

Bartov I, Bornstein S (1997) Stability of abdominal fat and meat of broilers: the interrelationship between the effects of dietary fat and vitamin E supplements. Br Poult Sci 18:59-68

Benamira M, Johnson K, Chaudary A, Bruner K, Tibbetts C, Marnett LJ (1995) Induction of mutations by replication of malondialdehyde-modified M13 DNA in Escheria coli: determination of the extent of DNA modification, genetic requirements for mutagenesis and type of mutation induced. Carcinogenesis 16:93-99

Boyd NF, McGuire V (1991) The possible role of lipid peroxidation in breast cancer risk. Free Radic Biol Med 10:185-190

Endo A (1979) Monacolin K, a new hypocholesterolemic agent produced by Monascus species. J Antibiot 32:852-854

Grau A, Guardiola F, Grimpa S, Barroeta AC, Codony R (2001) Oxidative stability dark chicken meat through frozen storage: influence of dietary fat and $\alpha$-tocopherol and ascorbic acid supplementation. Poult Sci 80:1630-1642

Harmon AW, Harp JB (2001) Differential effects of flavonoids on 3T3-L1 adipogenesis and lipolysis. Am J Physiol Cell Physiol 280:807-813

Jeon T, Hwang SG, Hirai S, Matsui T, Yano H, Kawada T, Lim BO, Park DK (2004) Red yeast rice extracts suppress adipogenesis by down-regulating adipogenic transcription factors and gene expression in 3T3-L1 cells. Life Sci 75:3195-3203

Juzlova P, Rezanka T, Martinkova L, Kren V (1996) Long-chain fatty acids from Monascus purpureus. Phytochemistry 43:151153

Konjufca VH, Pesti GM, Bakalli RI (1997) Modulation of cholesterol levels in broilers meat by dietary garlic and copper. Poult Sci 76:1264-1271
Kono I, Himeno K (2000) Changes in $\gamma$-aminobutyric acid content during beni-koji making. Biosci Biotechnol Biochem 64:617619

Lin JH, Lin YH, Kuo CC (2002) Effect of dietary fish oil fatty acid composition, lipid oxidation and sensory property of chicken frankfurters during storage. Meat Sci 60:161-167

Lopez-Bote CJ, Grar JI, Gomaa EA, Flegal CJ (1998) Effect of dietary oat administration on lipid stability in broiler meat. $\mathrm{Br}$ Poult Sci 39:57-61

Manzoni M, Bergomi S, Rollini M, Cavazzoni V (1999) Production of statins by filamentous fungi. Biotechnol Lett 21:253-257

Martinkova L, Juzlova P, Kren V, Kucerouva Z, Havlicek V, Olsovsky P, Hovorka O, Rihova B, Vesly D, Vesela D, Ulrichova J, Prikrylova V (1999) Biological activities of oligoketide pigments of Monascus purpureus. Food Addit Contam 16:15-24

Mori AV, Mendonca CXJ, Santos CO (1999) Effect of dietary lipidlowering drugs upon plasma lipids and egg yolk cholesterol levels of laying hens. J Agric Food Chem 47:4731-4735

Naber EC (1990) Cholesterol content of egg: can and should the industry try to change it? Feedstuffs $62: 46-52$

O’Neill LM, Galvin K, Morrissey PA, Buckley DJ (1999) Effect of carnosine, salt and dietary vitamin $\mathrm{E}$ on the oxidative stability of chicken meat. Meat Sci 52:89-94

Pekkanen AN, Punsar S, Karvonen MJ (1992) Short and long term association of serum cholesterol with mortality. Am J Epidemiol $135: 1252-1258$

Pitman WA, Osgood DP, Smith D, Schaefer EJ, Ordovas JM (1998) The effects of diet and lovastatin on regression of fatty streak lesions and on hepatic and intestinal mRNA levels for the LDL-C receptor and HMG-CoA reductase in F1B hamsters. Atherosclerosis 138:43-52

Ponte PI, Mendes I, Quaresma M, Aquia MN, Lemos JP, Ferreira LM, Soares MA, Alfaia CM, Prates JA, Fontes CM (2004) Cholesterol levels and sensory characteristics of meat from broilers consuming moderate to high levels of alfalfa. Poult Sci $83: 810-814$

Rule DC (1997) Direct transesterification of total fatty acids of adipose tissue, and of freeze-dried muscle and liver with borontrifluoride in methanol. Meat Sci 46:23-32

Salih AM, Smith DM, Price JF, Dawson LE (1987) Modified extraction 2-thiobarbituric acid method for measuring lipid oxidation in poultry. Poult Sci 66:1483-1488

Skrivan M, Skrivanova V, Marounek M, Tumova E, Wolf J (2000) Influence of dietary fat source and copper supplementation on broiler performance, fatty acid profile of meat and depot fat, and on cholesterol content in meat. Br Poult Sci 41:608-614

Su YC, Huang JH (1976) Studies on the production of ankapigment. J Chin Agric Chem Soc 14:45-58

Tobert JA, Bell GD, Birtwell J, James I, Kukovetz WR, Pryor JS, Buntinx A, Holmes IB, Chao YS, Bolognese JA (1982) Cholesterol-lowering effect of mevinolin, an inhibitor of 3hydroxy-3-methyl-glutary-coenzyme A reductase, in healthy volunteers. J Clin Invest 68:913-919

Wang JJ, Pan TM (2003) Effect of red mold rice supplements on serum and egg yolk cholesterol levels of laying hens. J Agric Food Chem 51:4824-4829

Wang UL, Houng JY, Chang HS, Chien HCR, Hsu WH (1998) Selection of drug-resistant mutants Monascus pilosus for enhanced monacolin $\mathrm{K}$ production. J Chin Agric Chem Soc 36:192-200

Wong HC, Koehler PE (1981) Production and isolation of an antibiotic from Monascus purpureus and its relationship to pigment production. J Food Sci 46:589-592

Yasukawa K, Takahashi M, Natori S, Yamazaki M, Takeuchi M, Takido M (1994) Azaphilones inhibit tumor promotion by 12$o$-tetradecanoyl-phorbol-13-acetate. Oncology 45:108-112 